\title{
PENGARUH FREKUENSI PEMBERIAN Moina sp. SEBAGAI PAKAN AWAL PADA PEMELIHARAAN LARVA IKAN GABUS Channa striata DENGAN SISTEM AIR HIJAU
}

\author{
Adang Saputra***), Dedi Jusadi*\#, Muhammad Agus Suprayudi*), Eddy Supriyono*), dan \\ Mas Tri Djoko Sunarno*) \\ *) Departemen Budidaya, Fakultas Perikanan dan IImu Kelautan, Institut Pertanian Bogor \\ JI. Rasamala, Kampus IPB, Darmaga, Bogor 16680 \\ ${ }^{*}$ Balai Riset Perikanan Budidaya Air Tawar dan Penyuluhan Perikanan \\ Jl. Sempur No. 1, Bogor 16445
}

(Naskah diterima: 11 April 2018; Revisi final: 8 Oktober 2018; Disetujui publikasi: 8 Oktober 2018)

\begin{abstract}
ABSTRAK
Ikan gabus Channa striata merupakan salah satu komoditas ikan air tawar yang memiliki nilai ekonomis tinggi. Kendala dalam pengembangan budidaya ikan gabus adalah tingginya tingkat kematian pada stadia pemeliharaan larva. Tingginya kematian pada stadia larva karena kecukupan jumlah pakan dan nutrisi pakan awal yang tidak optimum. Tujuan percobaan adalah menentukan frekuensi pemberian Moina sp. yang tepat sebagai pakan awal pada pemeliharaan larva ikan gabus pada sistem air hijau (dengan menambahkan Chlorella sp.). Penelitian dirancang dengan rancangan acak lengkap. Perlakuan yang diberikan adalah frekuensi pemberian Moina sp. per hari sebagai pakan awal: A. enam kali tanpa pemberian Chlorella sp. (kontrol), B. enam kali + Chlorella sp., C. empat kali + Chlorella sp., dan D. dua kali + Chlorella sp. Hasil penelitian menunjukkan pemberian pakan awal dari jenis Moina sp. pada pemeliharan larva ikan gabus pada sistem air hijau dengan frekuensi pemberian dua, empat, dan enam kali dalam sehari memberikan performa sintasan $(93,42 \% 94,29 \%$ dan pertumbuhan tidak berbeda secara nyata $(P>0,05)$. Frekuensi pemberian Moina sp. sebanyak dua kali sehari merupakan perlakuan yang efektif untuk sintasan dan pertumbuhan larva ikan gabus pada pemeliharaan dengan sistem air hijau.
\end{abstract}

KATA KUNCl: larva ikan gabus; frekuensi pemberian pakan; Moina sp.; sintasan; pertumbuhan;
air hijau

ABSTRACT: Effects of different feeding frequencies using M oina sp. as an initial food on growth and survival of snakehead Channa striata larvae reared in green water system. By: Adang Saputra, Dedi Jusadi, Muhammad Agus Suprayudi, Eddy Supriyono, and Mas Tri Djoko Sunarno

\begin{abstract}
Snakehead fish Channa striata is one of the highly-valued freshwater fish commodity. However, its aquaculture development is hampered by a high mortality during larval stage rearing. This high mortality is suspected to be caused by insufficient quantity and quality of food. The purpose of this study was to determine the appropriate feeding frequency using Moina sp. as an initial food for snakehead fish larvae reared in a green water system (Chlorella sp.). A completely randomized design was arranged for this experiment where the treatments consisted of different feeding frequencies of Moina sp. given to the larvae as follows: A) six times a day without the addition of Chlorella sp. (control); B) six times a day with the addition of Chlorella sp.; C) four times a day with the addition of Chlorella sp.; and D) two times a day with the addition of Chlorella sp. The results of the experiment showed that the survival rate $(93.42 \%$ $94.29 \%$ and growth of the larvae reared in the green water system with were not significantly different $(P>0.05)$. However, this study suggested that feeding frequency of two times per day was sufficient to support an optimum growth and survival of snakehead larvae reared in a green water system.
\end{abstract}

KEYWORDS: larvae snakehead fish; feeding frequency; M oina sp.; survival; growth; green water

\footnotetext{
\# Korespondensi: Departemen Budidaya, Fakultas Perikanan dan

Ilmu Kelautan, Institut Pertanian Bogor. Jl. Rasamala,

Kampus IPB, Darmaga, Bogor 16680, Indonesia.

Tel. + $622518622909 ; 8622911$

E-mail: siflounder@gmail.com; dedidj@ apps.ipb.ac.id
} 


\section{PENDAHULUAN}

Ikan gabus Channa striata termasuk ikan air tawar yang mempunyai nilai ekonomis tinggi sebagai ikan konsumsi dalam bentuk segar maupun olahan (Kusmini et al., 2016), serta kandungan albuminnya yang mampu mempercepat proses penyembuhan luka setelah proses operasi (Wahab et al., 2015). Tingginya tingkat kematian selama stadia larva menjadi kendala dalam pengembangan budidaya ikan gabus (Amornsakun et al., 2011). Keberhasilan pemeliharaan larva ikan akan menentukan keberhasilan kegiatan pendederan dan pembesaran ikan gabus. Salah satu faktor yang diduga penyebab tingginya kematian larva ikan gabus adalah akibat penyediaan dan nutrien pakan awal yang tidak mencukupi. Hasil penelitian Amornsakun et al. (2011) menunjukkan bahwa pakan awal terbaik untuk larva ikan gabus adalah M oina sp.

Penyediaan pakan awal yang tidak sesuai menyebabkan kematian pada larva ikan baik pada lingkungan alami maupun pada wadah budidaya (Yúfera \& Darias, 2007). Kondisi ini menghambat perkembangan ontogenik, sehingga menurunkan aktivitas berenang dan nafsu makan larva ikan (Kestemont et al., 2007). Kekurangan nutrien pakan dapat menyebabkan kelainan morfologi dan perlambatan pertumbuhan (Nhu et al., 2010; Bonaldo et al., 2011), serta memengaruhi proses perkembangan larva ikan white sturgeon Acipenser transmontanus (Lee et al., 2014).

Strategi pemberian pakan awal yang tepat merupakan kunci keberhasilan dalam pemeliharaan larva ikan. Menurut Blaxter \& Ehrlich (1974), begitu cadangan pakan endogen habis maka larva melakukan transisi ke pakan eksogen untuk menjamin sintasan dan pertumbuhannya. Pakan eksogen yang diberikan pada umumnya pakan alami misalnya naupli Artemia sp. pada larva Octopus vulgaris (Iglesias et al., 2006), naupli kopepoda (Lindley et al., 2011), dan alga hijau (Lazo et al., 2000). Pada larva ikan gabus pakan awal yang diberikan adalah Moina sp. (Amornsakun et al., 2011). Permasalahan yang dihadapi dalam pemanfaatan M oina sp. adalah cepatnya degradasi nutrien pada tubuh M oina sp. jika pada wadah pemeliharaan ketersediaan makanan tidak mencukupi (Das et al., 2007). Degradasi nutrien pada M oina sp. berdampak terhadap rendahnya nutrien yang diterima larva ikan (Adeyemo et al., 1994).

Salah satu alternatif untuk menyediakan M oina sp. berkualitas baik bagi larva ikan gabus adalah melalui aplikasi "sistem air hijau" (green water system) yaitu dengan penambahan mikroalga pada media pemeliharaan Iarva ikan. Alternatif lainnya adalah melalui pemberian Moina sp. dengan frekuensi yang tepat pada pemeliharaan larva ikan gabus. Menurut Neori (2011), mikroalga hijau seperti Chlorella sp. memiliki peran penting dalam menyediakan nutrien bagi zooplankton dalam sistem budidaya. Penggunaan mikroalga hijau sebagai sistem air hijau mampu menyediakan protein dan lemak yang cukup tinggi sebagai sumber nutrien untuk pakan alami (Islam et al., 2017). Hasil penelitian Bouchnak et al. (2014) menunjukkan Moina macrocopa dan Moina micrura mampu memanfaatkan Chlorella sp. sebagai sumber nutrien dan mampu meningkatkan kandungan nutrien dari kedua jenis Moina tersebut. Penelitian terkait frekuensi pemberian pakan awal sudah dilakukan, antara lain pada larva ikan spotted seatrout Cynoscion nebulosus (Manley et al., 2015), larva ikan black sea bass Centropristis striata (Russo et al., 2017), dan larva amazonian fish Pyrrhulina brevis Steindachner, 1876 (Veras et al., 2014). Frekuensi pemberian naupli Artemia enam kali dalam satu hari mampu meningkatkan pertumbuhan yang lebih cepat pada larva uropean mudminnow Umbra krameri (Demeny et al., 2014). Frekuensi pemberian pakan empat kali sehari memberikan pengaruh terbaik untuk mendukung pertumbuhan dan sintasan larva ikan black sea bass Centropristis striata (Russo et al., 2017), enam kali sehari mampu meningkatkan pertumbuhan larva ikan spotted seatrout Cynoscion nebulosus (Manley et al., 2015). Namun frekuensi pemberian pakan awal yang tepat untuk pemeliharaan larva ikan gabus belum tersedia informasinya.

Indikator pertumbuhan larva ikan dalam keadaan optimum di antaranya pH dan konsentrasi $\mathrm{Ca}^{2+}$ cairan tubuh. Nilai pH dan konsentrasi $\mathrm{Ca}^{2+}$ cairan tubuh merefleksikan proses metabolisme dan proses fisiologis (Kwong et al., 2014), serta pertumbuhan pada stadia larva (Tataje et al., 2015). Perubahan gradien $\mathrm{pH}$ cairan tubuh memengaruhi perubahan sistem hormonal (Furukawa et al., 2011), stres (Mai et al., 2010), dan transpor aktif ion $\mathrm{Na}^{+}, \mathrm{H}^{+}$, dan $\mathrm{Cl}^{-}$ (Evans et al., 2005). Apabila pH dan $\mathrm{Ca}^{2+}$ cairan tubuh dalam keadaan tidak optimum memberikan pengaruh terhadap aktivitas enzim (Mai et al., 2010), pertumbuhan (Kakizawa et al., 1996) dan sintasan (Wilson et al., 1999).

Perkembangan aktivitas enzim pencernaan dapat merefleksikan efektivitas saluran pencernaan dalam memanfaatkan pakan, sehingga dapat digunakan sebagai indikator status nutrisi pada perkembangan larva (Chen et al., 2007). Menurut Wang et al. (2006), jenis enzim utama untuk mencerna makanan adalah protease, amilase, dan lipase. Menurut Micale et al. (2006), pada kondisi saluran pencernaan larva belum berkembang, sumber makanan larva bertumpu pada pakan alami seperti pada larva ikan chinese longsnout 
catfish Leiocassis longirostris (Günther) selama sepuluh hari (Liu et al., 2012), larva ikan butter catfish Ompok bimaculatus (Bloch) selama 7-17 hari (Pradhan et al., 2014), larva ikan white sea bream Diplodus sargus selama 2-13 hari (Guerreiro et al., 2010), dan larva ikan southern flounder (Paralichthys lethostigma) selama 11-23 hari (Cynthia et al., 2009).

Penelitian ini bertujuan untuk menentukan frekuensi pemberian Moina sp. sebagai pakan awal yang tepat pada pemeliharaan larva ikan gabus dengan sistem air hijau. Evaluasi dilakukan pada pertumbuhan dan sintasan larva ikan gabus yang dipelihara selama 15 hari.

\section{BAHAN DAN METODE}

\section{Waktu dan Tempat}

Percobaan dilaksanakan di Laboratorium Basah Nutrisi dan Teknologi Pakan, Balai Riset Perikanan Budidaya Air Tawar dan Penyuluhan Perikanan, Bogor. Percobaan dilaksanakan pada tahun 2007, selama 15 hari masa pemeliharaan.

\section{Wadah Pemeliharaan}

Sebanyak 12 buah akuarium kaca ukuran $40 \mathrm{~cm} x$ $40 \mathrm{~cm} \times 40 \mathrm{~cm}$, dengan ketinggian air $10 \mathrm{~cm}$ (volume air $16 \mathrm{~L}$ ) digunakan sebagai wadah percobaan. Air yang digunakan berasal dari sumur yang telah diendapkan selama dua hari. Setiap akuarium dilengkapi pemanas elektrik kapasitas 100 watt dan di-setting pada suhu $30^{\circ} \mathrm{C}$ untuk mendapatkan suhu air sekitar $29^{\circ} \mathrm{C}$. Masing-masing wadah dilengkapi aerasi yang bersumber dari aerator. Sisa pakan dan feses dibersihkan menggunakan teknik sifon. Selama percobaan tidak dilakukan pergantian air hanya menambah sesuai jumlah air yang berkurang karena penyifonan.

\section{Ikan Uji}

Larva ikan gabus yang digunakan berasal dari penijahan satu populasi induk generasi ke-2 (G-2) sebanyak tiga pasang (tiga jantan dan tiga betina) dengan ukuran rata-rata 300 g/induk. Setelah larva ikan gabus berumur dua hari dari menetas dengan bobot $0,42 \pm 0,08 \mathrm{~g}$ dan panjang $5,42 \pm 0,24 \mathrm{~mm}$ diambil secara acak, selanjutnya dimasukkan ke dalam wadah percobaan. Padat tebar dalam wadah percobaan adalah 50 ekor/L (800 ekor/wadah) (Amornsakun et al., 2011).

\section{Rancangan Percobaan}

Percobaan dirancang menggunakan rancangan acak lengkap dengan empat perlakuan dan tiga kali ulangan. Perlakuan yang diberikan adalah frekuensi pemberian M oina sp. sebagai pakan awal, yaitu: A. enam kali dalam sehari tanpa penambahan Chlorella sp. (kontrol); B. enam kali dalam sehari + Chlorella sp.; C. empat kali dalam sehari + Chlorella sp.; dan D. dua kali dalam sehari + Chlorella sp.

\section{Pemberian Moina sp. dan Chlorella sp.}

Moina sp. yang digunakan berasal dari kolam budidaya ikan lele milik masyarakat di Parung, Kabupaten Bogor. Sebelum digunakan sebagai pakan awal, M oina sp. dipelihara selama dua hari pada wadah berukuran $4.000 \mathrm{~L}$ yang sudah diberi Chlorella sp. Jumlah dan waktu pemberian M oina sp. disajikan pada Tabel 1. Chlorella sp. yang digunakan merupakan hasil kultur massal secara terkontrol dengan kepadatan 4,3 $\times 10^{9} \mathrm{sel} / \mathrm{mL}$ sebagai media sistem air hijau. Pemberian Chlorella sp. dilakukan dua kali dalam sehari yaitu pukul 07.00 WIB dan pukul 13.00 WIB sebanyak $250 \mathrm{~mL}$ setiap pemberian/wadah.

\section{Parameter Uji}

Data kematian larva ikan gabus dicatat setiap hari untuk menghitung sintasan pada akhir pemeliharaan (Huisman, 1987). Pengukuran bobot individu dan panjang total pada akhir perco baan dilakukan terhadap 30 ekor benih ikan gabus dari masing-masing wadah percobaan. Bobot individu diukur menggunakan timbangan digital dengan ketelitian dua desimal, sedangkan panjang total diukur menggunakan millimeter block. Sebanyak 10 ekor larva ikan gabus dari masingmasing perlakuan dikumpulkan menjadi satu (komposit/pool) kemudian digerus menggunakan mortar dan diambil cairan tubuhnya melalui proses sentrifugasi 7.000 rpm selama 10 menit. Selanjutnya cairan tubuh tersebut digunakan untuk pengukuran $\mathrm{pH}$ dan kalsium cairan tubuh dan diukur menggunakan pH-meter (Thermo Scientific pH bench) dan Ca-meter dengan ketelitian dua desimal.

Proses pengukuran aktivitas enzim dilakukan dengan mengambil larva ikan gabus secara acak sebanyak tiga ekor (bobot larva sekitar 2 g/ekor) dari masing-masing wadah percobaan pada akhir pemeliharaan. Selanjutnya larva ikan gabus ditimbang dan dihomogenisasi $(1 \mathrm{~g} / 10 \mathrm{~mL})$ dalam buffer dingin yang mengandung Tris- $\mathrm{HCl} 41-50 \mathrm{mM} ; \mathrm{CaCl}_{2} 20 \mathrm{mM}$ dengan $\mathrm{pH}$ 7,5; dan disentrifugasi dengan kecepatan $12.000 \mathrm{rpm}$ selama 15 menit pada suhu $4^{\circ} \mathrm{C}$. Supernatan diambil kemudian disimpan pada freezer $80^{\circ} \mathrm{C}$ untuk dianalisis total protein dan aktivitas enzimnya. Konsentrasi protein terlarut dalam sampel ditentukan dengan menggunakan albumin bovine serum sebagai standar (Bradford, 1976).

Aktivitas amilase dihitung berdasarkan Worthington (1991) menggunakan pati sebagai substrat. Larutan pati 1\%dalam 0,02 $\mathrm{M} \mathrm{Na}_{2} \mathrm{HPO}_{4}$ dan 


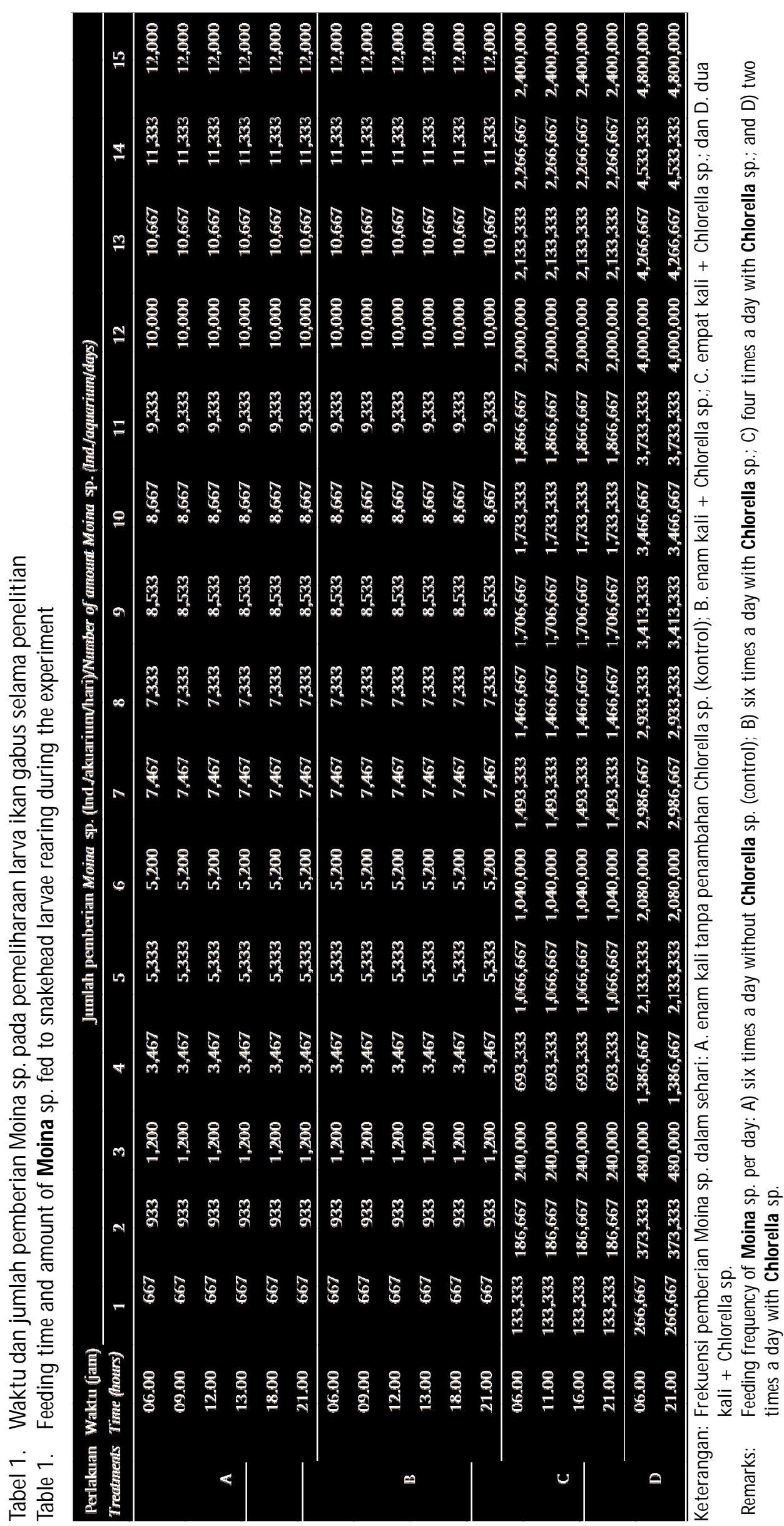


$0,006 \mathrm{M}$ buffer $\mathrm{NaCl}(\mathrm{pH} 6,9)$ diinkubasi menggunakan ekstrak enzim selama empat menit pada suhu $95^{\circ} \mathrm{C}$. Sebanyak 0,5 mL larutan asam dinitrosalisilat (DNS) $1 \%$ ditambahkan dan dipanaskan selama lima menit. Setelah larutan asam dinitrosalsilat mendidih, sebanyak $5 \mathrm{~mL}$ akuades ditambahkan pada campuran dan absorban kemudian diukur menggunakan spektrofotometer pada panjang gelombang $540 \mathrm{nM}$. Blanko disiapkan sama seperti untuk contoh, namun tanpa penambahan ekstrak enzim. Maltose sebanyak 0,3-5 $\mu \mathrm{mol} / \mathrm{mL}$ digunakan sebagai pembentuk kurva standar. Aktivitas spesifik $\alpha$-amilase didefinisikan sebagai $1 \mu \mathrm{g}$ maltose yang diproduksi per menit.

Aktivitas lipase dihitung menggunakan emulsi minyak zaitun sebagai substrat dan $\mathrm{Tris}-\mathrm{HCl}$ sebagai buffer sesuai dengan metode Borlongan (1990). Uji aktivitas enzim dilakukan dengan menambahkan $1 \mathrm{~mL}$ ekstrak enzim kasar ke dalam $1 \mathrm{~mL}$ substrat dalam $1,5 \mathrm{~mL}$ buffer yang mengandung Tris- $\mathrm{HCl} 0,1 \mathrm{M}$ pada pH 8,0. Campuran tersebut diinkubasi selama enam jam pada suhu $37^{\circ} \mathrm{C}$. Selanjutnya reaksi enzim dihentikan dengan penambahan $3 \mathrm{~mL}$ etilalkohol 95\% Proses selanjutnya adalah dititrasi dengan $0,01 \mathrm{~N}$ $\mathrm{NaOH}$. Thymolphthalein $0,9 \%(\mathrm{w} / \mathrm{v})$ dalam etanol digunakan sebagai indikator. Pembuatan blanko dilakukan dengan cara yang sama kecuali sampel ekstrak enzim kasar. Satu unit aktivitas enzim lipase (U) didefinisikan sebagai volume $(\mathrm{mL}) 0,01 \mathrm{~N} \mathrm{NaOH}$ yang diperlukan untuk menetralkan asam lemak yang dilepas dari substrat selama enam jam inkubasi. Aktivitas protease dikuantifikasi dengan menggunakan kasein sebagai substrat (Asgari et al., 2013). Lebih lanjut, $200 \mu \mathrm{L}$ ekstrak enzim kasar dicampur dengan $200 \mu \mathrm{L}$ substrat (1\%larutan kasein dalam $60 \mathrm{mM} \mathrm{HCl}$ ) dan diinkubasi selama 10 menit pada suhu $37^{\circ} \mathrm{C}$. Reaksi dihentikan dengan menggunakan $1 \mathrm{~mL}$ larutan $5 \% a s a m$ trikhloroasetat, diamkan selama 30 menit, selanjutnya tabung disentrifuse pada kecepatan $5.000 \mathrm{rpm}$ selama 20 menit pada suhu $4^{\circ} \mathrm{C}$. Sebanyak $0,5 \mu \mathrm{L}$ supernatan diinkubasi menggunakan $0,5 \mathrm{M} \mathrm{NaOH}(1 \mathrm{~mL})$ dan regen Folin-Ciocalteu $(0,3 \mathrm{~mL})$ selama 10 menit pada suhu $25^{\circ} \mathrm{C}$, selanjutnya absorban dari supernatan diukur menggunakan spektrofotometer pada panjang gelombang $720 \mathrm{~nm}$. Kurva standar yang digunakan adalah kurva standar tirosin 0-50 $\mu \mathrm{g} / \mathrm{mL}$. Satu unit protease didefinisikan sebagai sejumlah $\mu \mathrm{g}$ Tirosin yang dirilis per menit per $\mathrm{mL}$ pada suhu $37^{\circ} \mathrm{C}$.

\section{Analisis Data}

Data hasil perhitungan dianalisis menggunakan analisis variansi (ANAVA) dengan aplikasi program MINITAB 16 dan software Microsoft Excel 2013 untuk menampilkan grafik. Apabila hasilnya berbeda nyata, maka dilanjutkan dengan uji Duncan. Data yang dianalisis secara statistik kuantitatif meliputi: sintasan, bobot akhir, panjang total, pH cairan tubuh, kalsium cairan tubuh, dan aktivitas enzim.

\section{HASIL DAN BAHASAN}

Hasil perhitungan terhadap sintasan larva ikan gabus yang dipelihara pada sistem air hijau menunjukkan frekuensi pemberian pakan tidak memberikan pengaruh secara nyata $(P>0,05)$. Perhitungan sintasan dilakukan secara visual melalui penghitungan larva ikan gabus yang hidup pada akhir pemeliharaan. Sintasan Iarva ikan gabus sesuai perlakuan adalah: A. $91,96 \pm 0,52 \%$ B. $94,29 \pm 0,51 \%$ C. $93,92 \pm 0,26 \%$ dan D. $93,42 \pm 0,38 \%$ (Gambar 1 ).

Manajemen pemberian pakan termasuk didalamnya aplikasi frekuensi pemberian pakan memiliki peranan penting dalam menentukan keberhasilan pemeliharaan larva ikan (Villarroel et al., 2011). Hasil penelitian menunjukkan frekuensi pemberian pakan berbeda tidak memberikan pengaruh nyata terhadap sintasan larva ikan gabus yang dipelihara pada sistem air hijau $(P>0,05)$; namun berbeda sangat nyata dengan kontrol $(P<0,05)$. Kondisi ini menunjukkan pemeliharaan larva ikan gabus yang diberi air hijau cukup diberi pakan awal sebanyak dua kali dalam sehari. Hasil ini sesuai dengan hasil penelitian Nhu et al. (2010) dan Goddard (1996) yang menyatakan bahwa kecukupan nutrien dalam pakan awal menjadi penentu terhadap peningkatan sintasan dan pertumbuhan larva ikan yang dipelihara.

Penambahan Chlorella sp. dalam wadah pemeliharaan larva ikan gabus sebagai asupan nutrien bagi Moina sp. berdampak terhadap peningkatan kualitas M oina sp. Peningkatan kualitas nutrien M oina sp. melalui penambahan Chlorella sp. mampu mempertahankan performa Moina sp. dalam kondisi prima. Kondisi ini akan meningkatkan performa sintasan dan pertumbuhan larva ikan gabus. Hal ini sejalan dengan hasil penelitian Kibria et al. (2001) di mana peningkatan kualitas M oina australiensis mampu meningkatkan sintasan larva ikan silver perch Bidyanus bydianus. Lebih lanjut Martin et al. (2006) menyatakan bahwa pemberian Moina micrura dengan penambahan alga mampu meningkatkan sintasan postlarva udang putih Litopenaeus schmitti.

Pola pertambahan bobot individu larva ikan gabus yang dipelihara pada sistem air hijau terus meningkat dari awal sampai hari ke-15 (Gambar 2A). Bobot individu larva ikan gabus yang dipelihara pada sistem air hijau dengan frekuensi pemberian pakan dua kali dalam sehari relatif lebih tinggi dibandingkan perlakuan lainnya. Bobot akhir larva ikan gabus paling rendah diperoleh pada pemeliharaan tanpa pemberian air hijau (kontrol). 


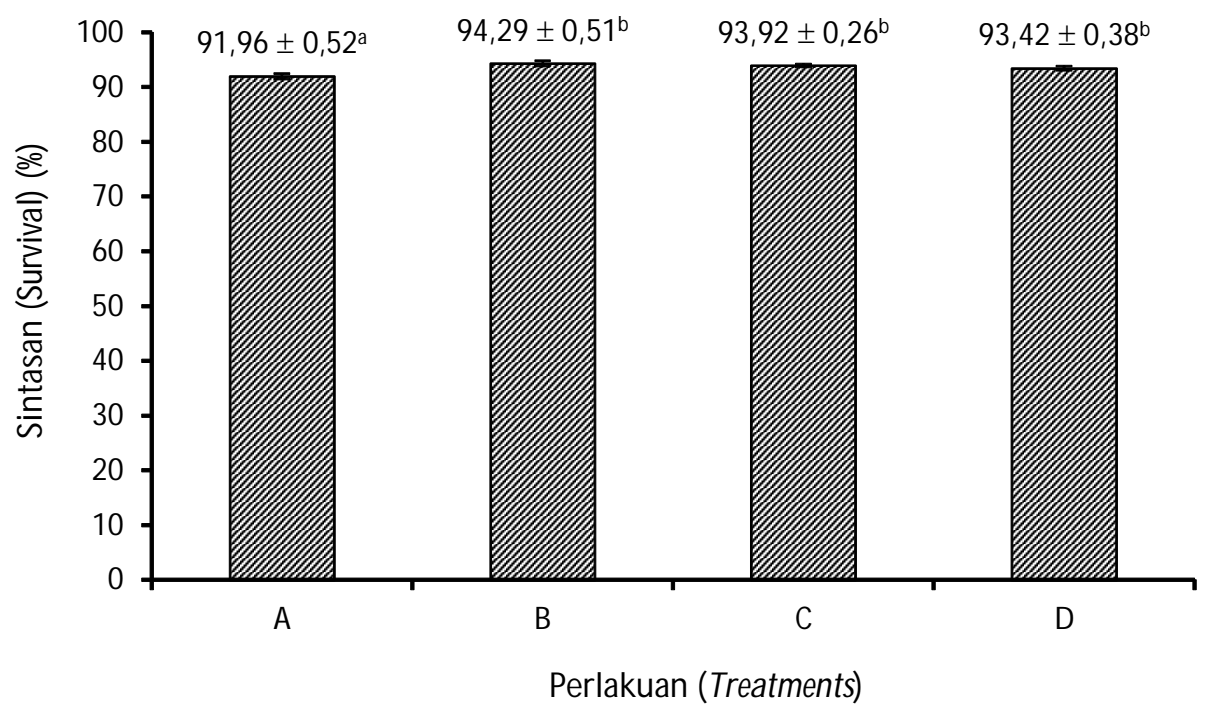

Keterangan: Frekuensi pemberian M oina sp. dalam sehari selama penelitian: A. enam kali tanpa penambahan Chlorella sp. (kontrol); B. enam kali + Chlorella sp.; C. empat kali + Chlorella sp. dan D. dua kali + Chlorella sp. Angka yang diikuti huruf superskrip yang sama menunjukkan tidak adanya perbedaan yang nyata $(P>0,05)$

Remarks: Daily feeding frequency of Moina sp. to snakehead fish larvae during the experiment A) six times a day without Chlorella sp. (control); B) six times a day with Chlorella sp.; C) four times a day with Chlorella sp.; and D) two times a day with Chlorella sp. Numbers followed by the same superscript letter indicates no significant difference $(P>0.05)$

Gambar 1. Sintasan larva ikan gabus C. striata yang dipelihara selama 15 hari.

Figure 1. Survival of snakehead fish $\mathbf{C}$. striata larvae after 15 days rearing period.

Frekuensi pemberian Moina sp. sebanyak enam kali sehari tanpa penambahan Chlorella sp. memberikan pertambahan bobot relatif paling rendah dibandingkan perlakuan lainnya. Kondisi ini menunjukkan M oina sp. kehabisan nutrien karena dipelihara pada kondisi tidak terdapat bahan organik, bakteri atau alga sebagai sumber makanannya. Sehingga dari sisi nutrisi, M oina sp. pada kondisi tersebut memiliki kandungan nutrisi yang rendah. Status nutrisi Moina sp. berdampak terhadap status nutrisi larva ikan gabus yang berperan sebagai predatornya. Kondisi ini berdampak secara langsung terhadap pertambahan bobot larva ikan gabus. Pertambahan bobot larva ikan gabus untuk perlakuan selain kontrol mengalami kenaikan secara signifikan diduga karena M oina sp. pada perlakuan ini telah memanfaatkan Chlorella sp. sebagai sumber nutrien. Hasil ini sesuai pendapat Lee et al. (2014) dan Adeyemo et al. (1994) yang menyatakan pertumbuhan larva ikan sangat dipengaruhi oleh kualitas pakan awal yang baik.

Derajat keasaman $(\mathrm{pH})$ cairan tubuh larva ikan gabus tidak berbeda nyata antar perlakuan $(P>0,05)$ seperti tertera pada Gambar 3A. Kondisi ini menunjukkan frekuensi pemberian pakan dua, empat, dan enam kali dalam sehari tidak berpengaruh secara nyata terhadap pH cairan tubuh larva ikan gabus selama diberi air hijau. Hasil perhitungan kalsium cairan tubuh larva ikan gabus tidak berbeda secara nyata $(P>0,05)$ seperti terlihat pada Gambar 3B. Kondisi ini menunjukkan frekuensi pemberian pakan tidak berpengaruh secara nyata terhadap kalsium cairan tubuh larva ikan gabus selama diberi air hijau.

Frekuensi pemberian Moina sp. tidak memberikan pengaruh nyata terhadap $\mathrm{pH}$ dan kalsium cairan tubuh larva ikan gabus di akhir masa pemeliharaan $(P>0,05)$. Nilai pH cairan tubuh larva ikan gabus berkisar antara 4,45-9,67 sedangkan kalsium cairan tubuh berkisar antara 150-9.083 mg/L. Kondisi ini merefleksikan proses metabolisme dan proses fisiologis larva ikan gabus berjalan dengan o ptimum. Terlihat dari performa sintasan dan pertumbuhan larva ikan gabus dalam keadaan optimum. Menurut Barton et al. (1987) dan Li et al. (2014), apabila ikan mengalami stres dapat menyebabkan kematian padalarva ikan yang dipelihara.

Pemberian pakan dengan frekuensi yang berbeda memberikan pengaruh nyata terhadap aktivitas lipase $(\mathrm{P}<0,05)$. Performa larva ikan gabus yang dipelihara 

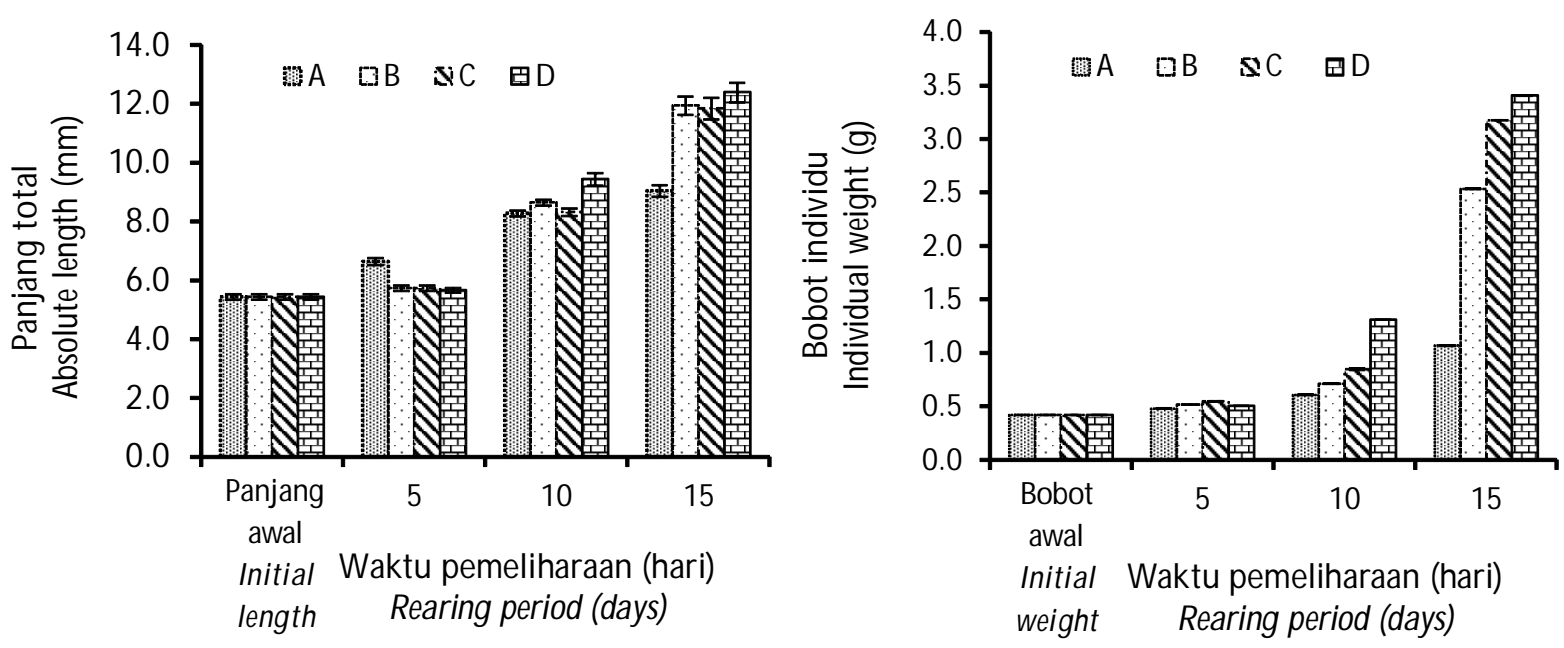

Keterangan; Frekuensi pemberian M oina sp. dalam sehari selama penelitian: A. enam kali tanpa penambahan Chlorella sp. (kontrol); B. enam kali + Chlorella sp.; C. empat kali + Chlorella sp., dan D. dua kali + Chlorella sp.

Remarks: Daily feeding frequency of Moina sp. to snakehead fish larvae during the experiment: A) six times a day without Chlorella sp. (control); B) six times a day with Chlorella sp.; C) four times a day with Chlorella sp.; and D) two times a day with Chlorella sp.)

Gambar 2. Pola pertambahan larva ikan gabus selama 15 hari masa pemeliharaan; (A) panjang total, (B) bobot individu.

Figure 2. Growth pattern of snakehead fish larvae during 15 days rearing period; (A) absolute length, (B) individual weight.
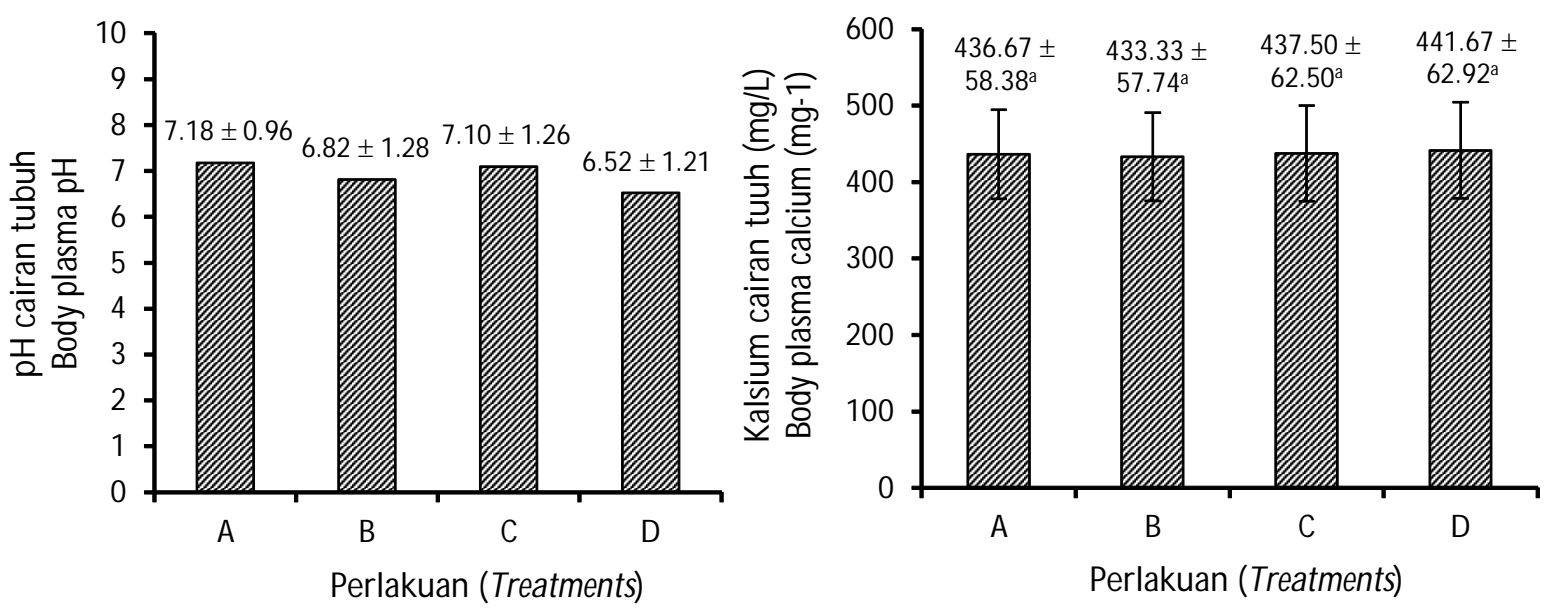

Keterangan: Frekuensi pemberian Moina sp. dalam sehari selama penelitian: A. enam kali tanpa penambahan Chlorella sp. (kontrol); B. enam kali + Chlorella sp.; C. empat kali + Chlorella sp., dan D. dua kali + Chlorella sp. Angka yang diikuti huruf superskrip yang sama menunjukkan tidak ad anya perbedaan yang nyata $(\mathrm{P}>0,05)$.

Remarks: Daily feeding frequency of Moina sp. to snakehead fish larvae during the experiment: A) six times a day without Chlorella sp. (control); B) six times a day with Chlorella sp.; C) four times a day with Chlorella sp.; and D) two times a day with Chlorella sp. Numbers followed by the same superscript letter indicates no significant difference $(P>0.05)$

Gambar 3. (A) pH cairan tubuh larva ikan gabus C. striata dan (B) kalsium cairan tubuh larva ikan gabus C. striata yang dipelihara selama 15 hari.

Figure 3. (A) body plasma pH of snakehead fish $\mathrm{C}$. striata larvae and (B) body plasma calcium of snakehead fish C. striata larvae after 15 days rearing period. 

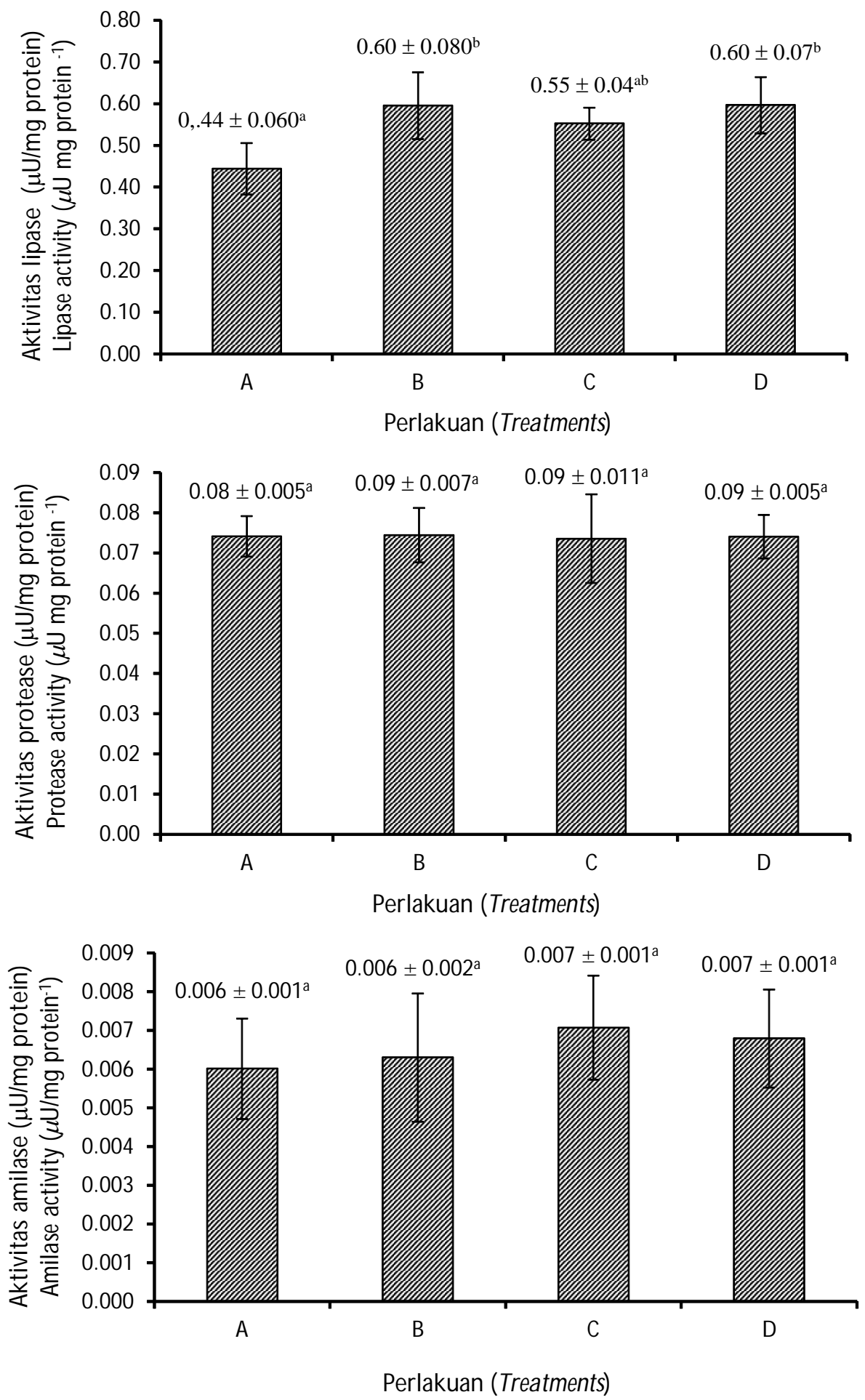

Keterangan: Frekuensi pemberian Moina sp. dalam sehari selama penelitian: A. enam kali tanpa penambahan Chlorella sp. (kontrol); B. enam kali + Chlorella sp.; C. empat kali + Chlorella sp. dan D. 2 kali + Chlorella sp. Angka yang diikuti huruf superskrip yang sama menunjukkan tidak adanya perbedaan yang nyata $(P>0,05)$

Remarks: Daily feeding frequency of Moina sp. to snakehead fish larvae during the experiment: A) six times a day without Chlorella sp. (control); B) six times a day with Chlorella sp.; C) four times a day with Chlorella sp.; and D) two times a day with Chlorella sp. Numbers followed by the same superscript letter indicates no significant difference $(\mathrm{P}>0.05)$

Gambar 4. Aktivitas lipase, protease, dan amilase (mU/mg protein) larva ikan gabus C. striata yang dipelihara selama 15 hari.

Figure 4. Lipase, protease, and amilase ( $\mathrm{mU} / \mathrm{mg}$ protein) activity in snakehead C. striata larvae 15 days rearing period. 
tanpa air hijau dengan frekuensi pemberian pakan enam kali memiliki aktivitas lipase 0,44 $\pm 0,06 \mathrm{mU} /$ mg protein; sedangkan aktivitas lipase larva ikan gabus yang dipelihara pada air hijau dengan frekuensi pemberian pakan enam, empat, dan dua kali sehari berturut-turut: $0,60 \pm 0,08 ; 0,55 \pm 0,04 ;$ dan $0,60 \pm$ $0,06 \mathrm{mU} / \mathrm{mg}$ protein (Gambar 4). Hasil ini menggambarkan aktivitas lipase dipengaruhi secara nyata oleh pemberian Chlorella sp. namun tidak dipengaruhi oleh frekuensi pemberian Moina sp.

Aktivitas protease larva ikan gabus yang dipelihara pada sistem air hijau dengan berbagai frekuensi pemberian pakan tidak berbeda nyata $(P>0,05)$ (Gambar 4). Larva ikan gabus yang dipelihara tanpa air hijau dengan frekuensi pemberian pakan enam kali sehari aktivitas proteasenya relatif paling rendah dibandingkan yang diberi air hijau. Kondisi ini menggambarkan aktivitas enzim protease larva ikan gabus yang dipelihara pada air hijau tidak dipengaruhi oleh frekuensi pemberian pakan dua, empat, dan enam kali sehari.

Hasil perhitungan aktivitas amilase larva ikan gabus yang tidak diberi air hijau $(0,006 \pm 0,001 \mathrm{mU} / \mathrm{mg}$ protein) lebih rendah dibandingkan dengan yang diberi air hijau. Aktivitas amilase larva ikan gabus yang dipelihara pada air hijau dengan berbagai frekuensi pemberian pakan tidak berbeda nyata $(P>0,05)$ (Gambar 4). Frekuensi pemberian Moina sp. berbeda tidak memberikan pengaruh nyata terhadap aktivitas enzim lipase, protease, dan amilase larva ikan gabus $(P>0,05)$ namun pemberian Chlorella sp. memberikan pengaruh nyata terhadap aktivitas lipase larva ikan gabus $(P<0,05)$. Aktivitas protease berkisar antara 0,084-0,086 $\mathrm{mU} / \mathrm{mg}$ protein sedangkan amilase berkisar antara 0,006-0,007 mU/mg protein. Berbeda dengan aktivitas protease dan amilase, aktivitas lipase dipengaruhi oleh frekuensi pemberian M oina sp. Berdasarkan kondisi tersebut, seluruh protein, lemak, dan karbohidrat yang terdapat dalam M oina sp. dapat dicerna dengan baik dan digunakan untuk memenuhi kebutuhan energi dan pembentukan jaringan bagi larva ikan gabus. Kondisi ini sesuai dengan penelitian Ribeiro et al. (1999) yang menyatakan bahwa aktivitas lipase pada ikan Solea senegalensis 2-8 kali lebih tinggi dibandingkan dengan aktivitas amilase. Tingginya aktivitas lipase pada awal perkembangan larva ikan menunjukkan proses pemanfaatan butir lemak (oil globe) yang terdapat pada kuning telur dan pola kenaikan aktivitas lipase akan diikuti penurunan aktivitas protease sampai kemudian mencapai titik konstan (Cahu \& Zambonino-Infante, 1994).

\section{KESIMPULAN}

Pemberian pakan awal dari jenis Moina sp. pada pemeliharan larva ikan gabus yang diberi air hijau (Chlorella sp.) dengan frekuensi pemberian pakan dua, empat, dan enam kali dalam sehari memberikan performa sintasan $(93,4 \% 94,3 \%$ dan pertumbuhannya tidak berbeda nyata. Frekuensi pemberian Moina sp. dua kali sehari sebagai pakan awal pada pemeliharaan larva ikan gabus dengan sistem air hijau paling efisien untuk sintasan dan pertumbuhan larva.

\section{UCAPAN TERIMA KASIH}

Penelitian ini dibiayai dari Anggaran Balai Riset Budiaya Air Tawar dan Penyuluhan Perikanan, Tahun Anggaran 2017.

\section{DAFTAR ACUAN}

Adeyemo, A.A., Oladosu, G.A., \& Ayinla, A.O. (1994). Growth and survival of fry of African catfish species, Clarias gariepinus Burchell, Heterobranchus bidorsalis Geoffery and Heteroclarias reared on Moina dubia in comparison with other first feed sources. Aquaculture, 119, 41-45.

Amornsakun, T., Sriwatana, W., \& Promkaew, P. (2011). Feeding behaviour of snake head fish Channa striatus larvae. Songklanakrin Journal of Science and Technology, 33, 665-670.

Asgari, R., Rafiee, G., Eagderi, S., Noori, F., Agh, N., Poorbagher, H., \& Gisbert, E. (2013). Ontogeny of the digestive enzyme activities in hatchery produced beluga Huso huso. Aquaculture, 417, 33-40.

Barton, B.A., Schreck, C.B., \& Barton, L.D. (1987). Effects of chronic cortisol administration and daily acute stress on growth, physiological conditions, and stress responses in juvenile rainbow trout. Dis. Aquat. Org., 2, 173- 185.

Blaxter, J.H.S. \& Ehrlich, K.F. (1974). Changes in behaviour during starvation of herring and plaice larvae. The early life history of fish. Berlin: Springer-Verlag, p. 575-588.

Bonaldo, A., Parma, L., Badiani, A., Serratore, P., \& Gatta, P.P. (2011). Very early weaning of common sole Solea solea L. larvae by means of different feeding regimes and three commercial microdiets: Influence on performances, metamorphosis development and tank hygiene. Aquaculture, 321, 237-244.

Borlongan, I.G. (1990). Studies on the digestive lipases of milkfish, Chanos chanos. Aquaculture, 89, 315-325. 
Bouchnak, R., Christian, E., \& Steinberg, V. (2014). Algae diets and natural xenobiotics impact energy allocation in cladocerans II. M oina macrocopa and M oina micrura. Limnologica-Ecology and M anagement of Inland Waters, 44, 23-31.

Bradford, M.M. (1976) A rapid and sensitive method for the quantitation of microgram quantities of protein utilizing the principle of protein dye binding. Ana. L. Biochem., 72, 248-254.

Cahu, C.L. \& Zambonino-Infante. (2004). Substitution of live food by formulated diets in marine fish larvae. Aquaculture, 200, 161-180.

Chen, B.N., Qin, J.G., Carragher, J.F., Clarke, S.M., Kumar, M.S., \& Hutchinson, W.G. (2007). Deleterious effects of food restrictions in yellowtail kingfish Seriola lalandi during early development. Aquaculture, 271, 326-335.

Cynthia K., Faulk, G., \& Holt, J. (2009). Early weaning of southern flounder, Paralichthys lethostigma, Iarvae and ontogeny of selected digestive enzymes. Aquaculture, 296, 213-218.

Das, S.K., Tiwari, V.K., Venkateshwarlu, G., Reddy, A.K., \& Chettri, J.K. (2007). Growth, survival and fatty acid composition of Macrobrachium rosenbergii (de Man, 1879) post larvae fed HUFAenriched Moina micrura. Aquaculture, 269, 464-475,

Demény, F., Trenovszki, M.M., Tatár, S., Sipos, S., Urbányi, B., \& Müller, T. (2014). Effect of feeding frequency on the growth of the european mudminnow larvae Umbra krameri WALBAUM, 1792 reared in controlled conditions. Bulgarian Journal of Agricultural Science, 20, 670-674.

Evans, D.H., Piermarini, P.M., \& Choe, K.P. (2005). The multifunctional fish gill: dominant site of gas exchange, osmoregulation, acid base regulation, and excretion of nitrogenous waste. Journal of Physiology Reverse, 85, 97-177.

Furukawa, F., Watanabe, S., Inokuchi, M., \& Kaneko, T. (2011). Responses of gill mitochondria-rich cells in mozambique tilapia exposed to acidic environments ( $\mathrm{pH} 4.0$ ) in combination with different salinities. Comparative Biochemistry Physiology, 158, 468-476.

Goddard, S. (1996). Feed management in intensive aquaculture. New York (US): Chapman and Hall, $194 \mathrm{pp}$.

Guerreiro, I., de Vareilles, M., Pousão-Ferreira, P., Rodrigues, V., \& Ribeiro, L. (2010). Effect of age at weaning on digestive capacity of white seabream Diplodus sargus. Aquaculture, 300, 194-205.

Huisman, E.A. (1987). The principles of fish culture production. Departement of Aquaculture.
Wageningen Agricultural University. Netherland, $311 \mathrm{pp}$.

Iglesias, J., Fuentes, L., Sánchez, J., Otero, J.J., Moxica, C., \& Lago, M.J. (2006). First feeding of Octopus vulgaris Cuvier, 1797 pralarvae using Artemia: Effect of prey size, prey density and feeding frequency. Aquaculture, 261, 817-822.

Islam, H., Alamin, M., Hasan, M.S., Mondal, S., \& Hossain, M.M.M. (2017). Fish culture in indoortank using green water technology. Journal of Entomology and Zoology Studies, 5, 2498-2502.

Kakizawa, S., Kaneko, T., \& Hirano, T. (1996). Elevation of plasma somatolactin concentrations during acidosis in rainbow trout Oncorhynchus mykiss. J. Exp. Biol., 199, 1043-1051.

Kestemont, P., Xueliang, X., Hamza, N., Maboudou, J., \& Toko, I.I. (2007). Effect of weaning age and diet on pikeperch larviculture. Aquaculture, 264, 197-204.

Kibria, Nugegoda, Fairclough, Lam, \& Bradley. (2001). Utilization of wastewater grown zooplankton: Nutritional quality of zooplankton and performance of silver perch Bidyanus bidyanus (Mitchell 1838) Teraponidae fed on wastewater grown zooplankton. Aquaculture Nutrition, 5, 221-227.

Kusmini, I,I., Gustiano, R., Prakoso, V.A., \& Ath-thar, M.H.F. (2016). Perbenihan dan budidaya ikan gabus. Jakarta: Penebar Swadaya, $76 \mathrm{hlm}$.

Kwong, R.W.M., Kumai, Y., \& Perry, S.F. (2014). The physiology of fish at low $\mathrm{pH}$ : the zebrafish as a model system. The Journal of Experimental Biology, 217, 651-662.

Lazo, J.P., Dinis, M.T., Holt, G.J., Faulk, C., \& Arnold, C.R. (2000). Co-feeding microparticulate diets with algae: toward eliminating the need of zooplankton at first feeding in larval red drum Sciaenops ocellatus. Aquculture, 188, 339-351.

Lee, S., Wang, Y., Hung, S.S.O., Strathe, A.B., Fangue, N.A., \& Fadel, J.G. (2014). Development of optimum feeding rate model for white sturgeon Acipenser transmontanus. Aquaculture, 433, 411-420.

Li, X.F., Tian, H.Y., Zhang, D.D., Jiang, G.Z., \& Liu, W.B. (2014). Feeding frequency affects stress, innate immunity and disease resistance of juvenile blunt snout bream M egalobrama amblycephala. Fish \& Shellfish Immunology, 38, 80-87.

Lindley, L.C., Phelps, R.P., Davis, D.A., \& Cummins, K.A. (2011). Salinity acclimation and free amino acid enrichment of copepod nauplii for first-feeding of larval marine fish. Aquaculture, 318, 402-406.

Liu, B., Zhu, X., Lei, W., Yang, Y., \& Xie, S. (2012). Effects of different weaning strategies on survival 
and growth in chinese longsnout catfish Leiocassis longirostris Günther larvae. Aquaculture, 364, 13-18.

Mai, W.J., Yan, J.L., Wang, L., Zheng, Y., Xin, Y., \& Wang, W.N. (2010). Acute acidic exposure induces p53-mediated oxidative stress and DNA damage in tilapia Oreochromis niloticus blood cells. Aquatic Toxicology, 100, 271-281.

Manley, C.B., Rakocinski, C.F., Lee, P.G., \& Blaylock, R.B. (2015). Feeding frequency mediates aggression and cannibalism in larval hatcheryreared spotted seatrout, Cynoscion nebulosus. Aquaculture, 437, 155-160.

Martin, L., Arenal, A., Fajardo, J., Pimentel, E., Hidalgo, L., Pacheco, M., García, C., \& Santiesteban, D. (2006). Complete and partial replacement of Artemia nauplii by M oina micrura during early postlarval culture of white shrimp Litopenaeus schmitti. Aquaculture Nutrition, 12, 89-96.

Micale, V., Garaffo, M., Genovese, L., Spedicato, M.T., \& Muglia, U. (2006). The ontogeny of the alimentary tract during larval development in common pandora Pagellus erythrinus L. Aquaculture, 251, 354-365.

Neori, A. (2011). "Green water" microalgae: The leading sector in world aquaculture. Journal of Applied Phycology, 23, 143-149.

Nhu, V.V., Dierckens, K., Nguyen, H.T., Hoang, T.M.T., $\&$ Sorgeloos, P. (2010). Effect of early co-feeding and different weaning diets on the performance of cobia Rachycentron canadum larvae and juveniles. Aquaculture, 305, 52-58.

Pradhan, P.K., Jena, J., Mitra, G., Sood, N., \& Gisbert, E. (2014). Effects of different weaning strategies on survival, growth and digestive system development in butter catfish Ompok bimaculatus (Bloch) larvae. Aquaculture, 424, 120-130.

Ribeiro, R., Zambonino-Infante, J.L., Cahu, C., \& Dinis, M.T. (1999). Development of digestive enzymes in larvae of Solea senegalensis, Kaup 1858. Aquaculture, 179, 465-473.

Russo, D.J., Watanabe, W.O., Kinsey, S.T., \& Seaton, P.J. (2017). Effects of feeding frequency of live prey on larval growth, survival, resistance to hyposalinity stress, $\mathrm{Na}^{+} / \mathrm{K}^{+}$ATPase activity, and fatty acid profiles in black sea bass Centropristis striata. Aquaculture, 470, 56-67.

Tataje, D.A.Y., Baldisserotto, B., \& Filho, E.Z. (2015). The effect of water $\mathrm{pH}$ on the incubation and larviculture of curimbatá Prochilodus lineatus Valenciennes, 1837 (Characiformes: Prochilodontidae). Neotropical Ichthyology, 13, 179-186.

Veras, G.C., Brabo, M.F., Dias, J.A., Abe, H.A., Nunes, M.P., \& Murgas, L.D.S. (2014). The effect of photoperiod and feeding frequency on larval of the amazonian ornamental fish Pyrrhulina brevis (Steindachner, 1876). Aquaculture Research, p. 1-7.

Villarroel, M., Alavriño, J.M.R., \& López-Luna, J. (2011). Effect of feeding frequency and one day fasting on tilapia Oreochromis niloticus and water quality. Israel Journal Aquaculture Bamidgeh, 63, 609-715.

Wahab, S.Z., Kadir, A.B., Hussein, N.H., Omar, J., Yunus, R., Baie, S., Noor, N.M., Hassan, I.I., Mahmood, W.H., Razak, A.B., \& Yusoff, W.Z. (2015). The effect of Channa striatus (Haruan) extract on pain and wound healing of post-lower segment caesarean section women. Ev-Based Comp. Alt. Med., 15, 1-7.

Wang, C., Xie, S., Zhu, X., Lei, W., Yang, Y., \& Liu, J. (2006). Effects of age and dietary protein level on digestive enzyme activity and gene expression of Pelteobagrus fulvidraco larvae. Aquaculture, 254, 554-562.

Wilson, R.W., Wood, C.M., Gonzalez, R.J., Patrick, M.L., Bergman, H.L., Narahara, A., \& Val, A.L. (1999). Ion and acid-base balance in three species of amazonian fish during gradual acidification of extremely soft water. Physiol. Biochem. Zool., 72, 277-285.

Worthington. (1991). Enzymes, the physics and chemistry of life. New York: Simon and Schuster Publisher, p. 171-173.

Yúfera, M. \& Darias, M.J. (2007). The onset of exogenous feeding in marine fish larvae. Aquaculture, 268, 53-63. 